\title{
Endophyte isolations from Syzygium cordatum and a Eucalyptus clone (Myrtaceae) reveal new host and geographical reports for the Mycosphaerellaceae and Teratosphaeriaceae
}

\author{
Angelica Marsberg • Bernard Slippers • Michael J. Wingfield • Marieka Gryzenhout
}

\begin{abstract}
Species of Mycosphaerellaceae and Teratosphaeriaceae (Ascomycetes) cause important leaf, shoot and canker diseases globally on a broad range of hosts, including Eucalyptus and other Myrtaceae. Recently, species of the Mycosphaerellaceae and Teratosphaeriaceae have been isolated as asymptomatic endophytes. In this study, endophytic species of Mycosphaerellaceae and Teratosphaeriaceae were isolated from samples taken from healthy native Syzygium cordatum (Myrtaceae) and related non-native Eucalyptus grandis x E. camaldulensis (hybrid clone) growing in Mtubatuba, KwaZulu Natal, South Africa. Multi-locus sequence analysis (MLSA) using the Internal Transcribed Spacer (ITS) region, the partial Large Subunit (LSU; 28S nrDNA) of the nuclear ribosomal DNA operon and Translation Elongation Factor- $1 \alpha$ (TEF- $1 \alpha)$ genes were used to correctly identify the 22 resulting isolates. The isolates grouped in five clades representing Readeriella considenianae that was isolated only from the Eucalyptus hybrid clone, Mycosphaerella marksii and $M$. vietnamensis from $S$. cordatum and Pseudocercospora crystallina from both $S$. cordatum and the Eucalyptus hybrid clone. Interestingly, the serious canker pathogen T. zuluensis was isolated from Eucalyptus leaves, although it is known only from stem and branch cankers. Of the species found, $R$. considenianae and M. vietnamensis were found in South Africa for the first time, while M. marksii, M. vietnamensis and P. crystallina were shown to naturally infect native $S$. cordatum for the first time. Despite the limited
\end{abstract}

\footnotetext{
A. Marsberg $\cdot$ B. Slippers $\cdot$ M. J. Wingfield

Department of Genetics, Forestry and Agricultural Biotechnology Institute, University of Pretoria, Private Bag x20, Hatfield, 0028 Pretoria, South Africa

M. Gryzenhout $\left(^{*}\right)$

Department of Plant Sciences, University of the Free State, PO Box

339, Bloemfontein 9300, South Africa

e-mail: GryzenhoutM@ufs.ac.za
}

number of trees sampled, the new host and distribution reports show that more intensive sampling, especially following an endophyte approach, will reveal more complete patterns of host preference and geographical distribution for these fungi.

Keywords Mycosphaerellaceae · Teratosphaeriaceae · Eucalyptus grandis $\cdot$ Syzygium cordatum $\cdot$ Native and non-native trees $\cdot$ South Africa

\section{Introduction}

Species of fungi in the Mycosphaerellaceae and Teratosphaeriaceae (Ascomycetes) previously resided in the single genus, loosely referred to as Mycosphaerella sensu lato (Capnodiales, Dothideomycetes). This group of fungi included approximately 3,000 species names with diverse ecological roles representing endophytes, pathogens and saprobes (Corlett 1995; Crous et al. 2000; Hunter et al. 2004, 2006; Crous et al. 2009c; Hunter et al. 2011). The pathogens in these genera include important leaf and shoot pathogens of a number of hosts, including Eucalyptus and other trees in the Myrtaceae. Collectively they cause the disease known as Mycosphaerella Diseases or Teratosphaeria Diseases (Hunter et al. 2011) in order to accommodate the groups that were previously defined solely as Mycosphaerella leaf blotch [MLB] or Mycosphaerella leaf diseases [MLD] (Crous et al. 1991; Hyde et al. 2007; Hunter et al. 2009; Sánchez Márquez et al. 2011). Globally, over 30 species of Mycosphaerella and Teratosphaeria, and their associated anamorph species, have been found to cause important leaf and canker diseases of Eucalyptus (Crous et al. 2000, 2004; Crous et al. 2006; Crous 2009; Crous et al. 2009a, b).

Morphological identification is difficult for species of the Mycosphaerellaceae and the Teratosphaeriaceae because they typically grow slowly in culture and many also sporulate only 
on host tissue (Crous 1998; Crous et al. 2001a; Hunter et al. 2004, 2006). Where morphology can be used for identification, it is based on the associated but morphologically variable anamorph genera (Crous 1998; Crous et al. 2001a; Hunter et al. 2004). Thus, in recent years, DNA sequence data from the Internal Transcribed Spacer (ITS) ribosomal DNA region has most frequently been used to identify the species in these two groups (Crous et al. 2001a, b; Hunter et al. 2004, 2006). Application of multi-gene analyses using sequences for the ITS region, Large Subunit (LSU) of the nuclear ribosomal DNA operon, Translation Elongation Factor- $1 \alpha$ (TEF-1 $\alpha)$ and Actin (Act) genes showed that Mycosphaerella was polyphyletic (Crous et al. 2001b; Hunter et al. 2006; Crous 2009). Consequently, this led to the separation of the families to include the Cladosporiaceae (Schubert et al. 2007; Bensch et al. 2010), Dissoconiaceae (Crous et al. 2009a), Teratosphaeriaceae and the Mycosphaerellaceae (Crous et al. 2007, 2009d). Following this taxonomic rearrangement, many species of Mycosphaerella have been transferred to the closely related Teratosphaeriaceae, which include pathogens of Eucalyptus such as Teratosphaeria cryptica, T. nubilosa, T. gauchensis and T. zuluensis amongst others (Crous et al. 2007; Andjic et al. 2010).

In South Africa, numerous species of the Mycosphaerellaceae and Teratosphaeriaceae are known to infect Eucalyptus trees (Crous and Wingfield 1996; Crous 1998; Hunter et al. 2004, 2011). Fewer species including M. syzygii, M. marasasii and P. syzygiicola have been found to be associated with the closely related native Myrtaceous tree, Syzygium cordatum (Sutton and Crous 1997; Crous 1999; Crous et al. 2001a). Previous studies identifying the Mycosphaerellaceae and Teratosphaeriaceae on Eucalyptus spp. and S. cordatum followed a broad approach where trees were sampled over a large geographic area. Furthermore, the samples were collected from diseased trees. In the present study, a more dense endophyte sampling approach was used to directly compare the Mycosphaerellaceae and Teratosphaeriaceae species endophyte assemblages from a single Eucalyptus grandis hybrid clone and S. cordatum tree. Samples were collected at the same time from the same geographical location and identified using the most recently available multi-locus sequence phylogenies.

\section{Materials and methods}

Sample collection

A $S$. cordatum tree was sampled in a private nature reserve in the Mtubatuba area of KwaZulu Natal, South Africa (E32'9" 54.1; S28'29"53.0). An E. grandis x E. camaldulensis hybrid clone was selected in an adjacent plantation approximately $500 \mathrm{~m}$ from the $S$. cordatum tree. Four leaves from each of four twigs that originated from four branches located in different positions, and a trunk increment core with the bark attached, were collected from each tree. Ten disks (approximately $5 \mathrm{~mm}$ in diameter) were cut from each leaf and 5 pieces ( $3 \mathrm{~mm}$ long) were taken from each twig and branch. Trunk increments were approximately $5 \mathrm{~mm}$ in diameter. The material was surface disinfected by first immersing them in $10 \%$ hydrogen peroxide $\left(\mathrm{H}_{2} \mathrm{O}_{2}\right)$ for $3-5 \mathrm{~min}$, followed by two washes of $1 \mathrm{~min}$ each with sterilised distilled water.

After surface disinfection, the samples from the Eucalyptus and S. cordatum were plated onto $2 \%$ Malt Extract Agar (MEA) (20 g malt extract, $20 \mathrm{~g}$ agar, $1 \mathrm{~L}$ distilled water; Biolab, Midrand, South Africa). These were incubated at $25^{\circ} \mathrm{C}$ for a month to allow for slow growing endophytic fungi to emerge. The endophytic fungi resembling the Mycosphaerellaceae and Teratosphaeriaceae that emerged were purified by transferring them to new MEA plates and further incubated at $25^{\circ} \mathrm{C}$. Primary isolations were monitored for a month to ensure that these slow growing fungi were all captured. Approximately 50 isolates emerged of which only a subset of these were used in the study. These cultures are maintained in the Culture Collection (CMW) of the Forestry and Agricultural Biotechnology Institute (FABI), Pretoria, South Africa.

\section{Multi-locus sequence analysis}

Mycelium was scraped from the surface of cultures growing on $2 \%$ MEA and freeze dried for $24 \mathrm{~h}$. DNA was subsequently extracted using a modified CTAB method (Moller et al. 1992). After precipitating the DNA, the supernatant was discarded and the DNA pellet was washed twice with $100 \mu \mathrm{l}$ of $70 \%$ ethanol and centrifuged at 10,000 rpm for $5 \mathrm{~min}$ for each wash step. The ethanol was removed and the pellet was air dried after the second wash until all the ethanol evaporated. The DNA pellet was re-suspended in $50 \mu \mathrm{l}$ nuclease-free water and allowed to incubate overnight at $4{ }^{\circ} \mathrm{C}$ (Moller et al. 1992). The DNA concentration of each sample was determined using a NanoDrop ${ }^{\mathrm{TM}} 1000$ Spectrophotometer version 3.7 (Thermo Fisher Scientific Inc., Germiston, South Africa) and the working DNA stocks were diluted to $40 \mathrm{ng} / \mu \mathrm{l}$ with nuclease-free water.

The full-length ITS region of the ribosomal operon was amplified for each sample. PCR amplification was performed in a 2720 Thermal Cycler (Applied Biosystems, Foster City, CA, USA) using the V9G (de Hoog and Gerrits van den Ende 1998) and ITS4 (White et al. 1990) primer pair. The volume for each reaction was $25 \mu \mathrm{l}$ with $40 \mathrm{ng}$ of template DNA, 10 pmoles of each primer (Integrated DNA Technologies, Coralville, Iowa, USA), $1 \times \mathrm{NH}_{4}$ Reaction Buffer (Roche Products Pty Ltd, South Africa), $1.5 \mathrm{mM} \mathrm{MgCl}_{2}$ (Roche Products Pty Ltd, South Africa), $75 \mu \mathrm{M}$ dNTPs (Roche 
Products Pty Ltd, South Africa) and 5 units of Fast Start Taq (Roche Products Pty Ltd, South Africa). Nuclease-free water was added to obtain a final volume of $25 \mu \mathrm{l}$. The cycle parameters were as follows: $94{ }^{\circ} \mathrm{C}$ denaturation for $5 \mathrm{~min}$, followed by 35 cycles of denaturation for $30 \mathrm{~s}$ at $94{ }^{\circ} \mathrm{C}$, annealing at $50{ }^{\circ} \mathrm{C}$ for $30 \mathrm{~s}$, and elongation at $72{ }^{\circ} \mathrm{C}$ for $45 \mathrm{~s}$. A final extension step followed at $72{ }^{\circ} \mathrm{C}$ for $7 \mathrm{~min}$. The primers used to amplify the TEF- $1 \alpha$ were EF1-728 F and EF1-986R (Carbone and Kohn 1990) while LROR (Moncalvo et al. 1995) and LR7 (Vilgalys and Hester 1990) were used to amplify the partial LSU (28S nrDNA) of the nuclear ribosomal DNA operon. The cycling conditions for the ITS and TEF- $1 \alpha$ were identical, while those for the LSU consisted of an initial denaturation step of $96{ }^{\circ} \mathrm{C}$ for $2 \mathrm{~min}$, followed by 35 cycles of denaturation at $94{ }^{\circ} \mathrm{C}$ for $30 \mathrm{~s}$, annealing at $55{ }^{\circ} \mathrm{C}$ for $30 \mathrm{~s}$, and elongation at $72{ }^{\circ} \mathrm{C}$ for 1 min with a final extension step at $72{ }^{\circ} \mathrm{C}$ for $7 \mathrm{~min}$.

The PCR products were cleaned with Sephadex G-50 columns (Steinheim, Germany) to enable direct DNA sequencing. The cleaned PCR product was used as a template for each sequencing reaction performed with the ABI PRISM $^{\mathrm{TM}}$ Big Dye Terminator Cycle Sequencing Ready Reaction Kit 3.1 (Applied Biosystems, Forster City, CA). Forward and reverse sequencing was performed with the same primers used for the PCR amplification. However, two additional internal primers, namely LR3R (Vilgalys and Hester 1990) and LR5 (Rehner and Samuels 1995) were required for the LSU region. The sequencing reactions were subsequently run on an ABI PRISM ${ }^{\mathrm{TM}} 3100$ automated DNA sequencer (Applied Biosystems, Foster City, CA) and the resultant sequences were manually analysed with CLC Main Workbench version 5.6 (CLC Bio A/S, Aarhus, Denmark) to assemble contigs with both the forward and reverse sequences. The sequences were identified by BLAST analysis on the GenBank database housed at the National Centre for Biotechnology Information (NCBI; www.ncbi.nlm.nih.gov).

In order to assign the isolates to genera, the LSU sequences were aligned with those for all species belonging to the Mycosphaerellaceae and Teratosphaeriaceae using MAFFT version 5.667 (Katoh et al. 2005) and a dataset with reference sequences provided by Dr E. W. Groenewald (CBS-KNAW Fungal Biodiversity Centre; Netherlands). The auto algorithm was employed in MAFFT as it automatically selects the appropriate strategy for the size of the dataset. A neighbourjoining tree, with complete deletion, was produced in MEGA version 4.0 (Tamura et al. 2007) to determine the genera in which the isolates could be placed. Due to the large size of the dataset (data not shown), only the species representing the nearest neighbours to the isolates of unknown identity were retained for further analyses.

The ITS and TEF- $1 \alpha$ sequences of these nearest neighbours were obtained from GenBank and included in the additional datasets. The ITS data set consisted of 33 taxa, which included 22 sequences generated in this study and 11 reference sequences. The LSU dataset consisted of 34 taxa, of which 22 were generated sequences and 12 were reference sequences. The TEF- $1 \alpha$ dataset was comprised of 36 taxa, including 22 generated sequences and 14 reference sequences. The sequences for the three gene regions were aligned using the auto algorithm in MAFFT version 5.667 (Katoh et al. 2005). The combined ITS/LSU/TEF- $1 \alpha$ dataset consisted of 33 taxa, of which 22 sequences were generated and 11 were reference sequences.

Parsimony trees were constructed for the individual and combined datasets using PAUP version 4.0 b10 (Swofford 2003). The heuristic search function with random sequence additions (100) and the Tree Bisection Reconnection (TBR) algorithm was used to obtain the equally most parsimonious trees. All uninformative characters, including gaps and missing data, were excluded and characters were reweighted according to the consistency index (CI). Bootstrap values were calculated after 1,000 replicates to determine the level of branch support (Felsenstein 1985). Tree length (TL), consistency index (CI), retention index (RI) and the homoplasy index (HI) were all calculated to assess the trees for signal, noise and reliability (Hillis and Huelsenbeck 1992). A partition homogeneity test (PHT) consisting of 1,000 replicates was used to determine whether the ITS, LSU and TEF- $1 \alpha$ datasets could be combined (Farris et al. 1994). The trees were rooted to Neofusicoccum ribis and Phaeobotryosphaeria visci as they are sister taxa to the Mycosphaerellaceae and Teratosphaeriaceae in the Dothiodeomycetes (Maxwell et al. 2005).

MrBayes version 3 was used for Bayesian analyses of the various datasets (Ronquist and Huelsenbeck 2003). MrModeltest version 2.2 was first used to determine the nucleotide substitution model that would best fit the individual datasets (Nylander 2004). The Markov Chain Monte Carlo (MCMC) analyses of six chains from random tree topology were made twice on 1,000,000 generations and trees were saved every 1,000 generations. Tracer version 1.4 was used to determine the posterior probabilities indicating the level of branch support (Rambaut and Drummond 2007).

\section{Results}

Multi-locus sequence analysis

Sequence data were obtained for 22 isolates, of which nine were from the $S$. cordatum tree and 13 from the E. grandis $\mathrm{x}$ E. camaldulensis clone (Table 1). Maximum parsimony and Bayesian analyses were done on the individual and combined datasets (Figs. 1, 2, 3, and 4) with appropriate models as determined by MrModeltest version 2.2 (Table 2). The maximum parsimony and Bayesian trees for the individual and combined datasets had similar topologies, although clades 
Table 1 Details of the fungal species and reference sequences used in the phylogenetic analyses

\begin{tabular}{|c|c|c|c|c|c|c|c|}
\hline \multirow[t]{2}{*}{ Species } & \multicolumn{2}{|c|}{ Accession } & \multirow[t]{2}{*}{ Host } & \multirow[t]{2}{*}{ Country } & \multicolumn{3}{|c|}{ Genbank accession } \\
\hline & $\mathrm{CMW}^{\mathrm{a}}$ & $\mathrm{CBS}^{\mathrm{b}}$ & & & ITS & LSU & TEF- $1 \alpha$ \\
\hline \multirow[t]{4}{*}{ Mycosphaerella ellipsoidea } & - & CBS 110843 & Eucalyptus sp. & South Africa & AY725545 & - & - \\
\hline & 4934 & - & Eucalyptus sp. & South Africa & - & DQ246253 & DQ235129 \\
\hline & - & CBS 110843 & Eucalyptus sp. & South Africa & - & GQ852602 & - \\
\hline & 5166 & - & Eucalyptus sp. & South Africa & - & - & DQ235127 \\
\hline \multirow[t]{3}{*}{ Mycosphaerella endophytica } & - & CBS 114662 & Eucalyptus sp. & South Africa & DQ302953 & GU214435 & - \\
\hline & 5225 & - & Eucalyptus sp. & South Africa & - & - & DQ235128 \\
\hline & 14912 & CBS 111519 & Eucalyptus sp. & South Africa & DQ267579 & - & DQ235131 \\
\hline \multirow[t]{3}{*}{ Mycosphaerella marksii } & 14781 & CBS 682.95 & E. grandis & South Africa & DQ267587 & DQ246249 & DQ235133 \\
\hline & 5230 & - & E. botryoides & Australia & DQ267588 & DQ246246 & DQ235135 \\
\hline & 37697 & & Syzygium cordatum & South Africa & JQ732925 & JQ732974 & JQ733021 \\
\hline \multirow[t]{4}{*}{ Mycosphaerella marksii } & 33962 & & S. cordatum & South Africa & JQ732926 & JQ732975 & JQ733022 \\
\hline & 37682 & & S. cordatum & South Africa & JQ732929 & JQ732978 & JQ733025 \\
\hline & 37694 & & S. cordatum & South Africa & JQ732930 & JQ732979 & JQ733026 \\
\hline & 38277 & & S. cordatum & South Africa & JQ732931 & JQ732980 & JQ733026 \\
\hline \multirow[t]{4}{*}{ Mycosphaerella vietnamensis } & 23442 & - & E. camaldulensis & Vietnam & DQ632678 & EU882135 & - \\
\hline & 23441 & CBS 119974 & E. grandis & Vietnam & DQ632675 & JF700944 & - \\
\hline & 37695 & & S. cordatum & South Africa & JQ732923 & JQ732972 & JQ733019 \\
\hline & 37696 & & S. cordatum & South Africa & JQ732924 & JQ732973 & JQ733020 \\
\hline \multirow[t]{4}{*}{ Pseudocercospora crystallina } & 3042 & - & E. bicostata & South Africa & DQ267578 & DQ204746 & DQ211662 \\
\hline & 3033 & CBS 681.95 & E. bicostata & South Africa & DQ632681 & DQ204747 & DQ211663 \\
\hline & 38912 & & Eucalyptus grandis $\mathrm{x}$ E. camaldulensis & South Africa & JQ732911 & JQ732960 & JQ733008 \\
\hline & 38913 & & S. cordatum & South Africa & JQ732927 & JQ732976 & JQ733023 \\
\hline Pseudocercospora crystallina & 37698 & & S. cordatum & South Africa & JQ732932 & JQ732981 & JQ733028 \\
\hline \multirow[t]{8}{*}{ Readeriella considenianae } & - & - & E. stellulata & Australia & GQ852792 & GQ852681 & - \\
\hline & - & - & E. stellulata & Australia & GQ852791 & GQ852680 & - \\
\hline & 37671 & & E. grandis $\mathrm{x}$ E. camaldulensis & South Africa & JQ732893 & JQ732942 & JQ732990 \\
\hline & 37674 & & E. grandis $\mathrm{x}$ E. camaldulensis & South Africa & JQ732896 & JQ732945 & JQ732994 \\
\hline & 37675 & & E. grandis $\mathrm{x}$ E. camaldulensis & South Africa & JQ732897 & JQ732946 & JQ732995 \\
\hline & 37676 & & E. grandis $\mathrm{x}$ E. camaldulensis & South Africa & JQ732899 & JQ732948 & JQ732997 \\
\hline & 37678 & & E. grandis $\mathrm{x}$ E. camaldulensis & South Africa & JQ732901 & JQ732950 & JQ732999 \\
\hline & 37680 & & E. grandis $\mathrm{x}$ E. camaldulensis & South Africa & JQ732903 & JQ732952 & JQ733001 \\
\hline \multirow[t]{2}{*}{ Teratosphaeria molleriana } & 4940 & CBS 111164 & E. globulus & Portugal & AF309620 & DQ246220 & DQ235104 \\
\hline & 2734 & CBS 111132 & E. globulus & U.S.A. & AF309619 & DQ246223 & DQ235105 \\
\hline \multirow[t]{2}{*}{ Teratosphaeria zuluensis } & 17320 & - & E. grandis & Zambia & DQ240148 & EU019296 & DQ240206 \\
\hline & 15833 & & Eucalyptus sp. & Mexico & - & - & DQ240162 \\
\hline \multirow[t]{6}{*}{ Teratosphaeria zuluensis } & 37669 & & E. grandis $\mathrm{x}$ E. camaldulensis & South Africa & JQ732891 & JQ732940 & JQ732988 \\
\hline & 37670 & & E. grandis $\mathrm{x}$ E. camaldulensis & South Africa & JQ732892 & JQ732941 & JQ732989 \\
\hline & 37672 & & E. grandis $\mathrm{x}$ E. camaldulensis & South Africa & JQ732894 & JQ732943 & JQ732992 \\
\hline & 37679 & & E. grandis $\mathrm{x}$ E. camaldulensis & South Africa & JQ732902 & JQ732951 & JQ733000 \\
\hline & 37690 & & E. grandis $\mathrm{x}$ E. camaldulensis & South Africa & JQ732915 & JQ732964 & JQ733012 \\
\hline & 37693 & & E. grandis $\mathrm{x}$ E. camaldulensis & South Africa & JQ732920 & JQ732969 & JQ733016 \\
\hline Neofusicoccum ribis & 7773 & - & Ribes sp. & U.S.A. & DQ246604 & DQ246263 & DQ235142 \\
\hline Phaeobotryosphaeria visci & - & CBS 100163 & Sphaeropsis visci & Germany & EU673324 & DQ377870 & EU673292 \\
\hline
\end{tabular}

Genbank accessions in bold were used in the combined analyses

${ }^{\mathrm{a}} \mathrm{CMW}=$ Culture collection of the Forestry and Agricultural Biotechnology Institute (FABI), University of Pretoria, South Africa

${ }^{\mathrm{b}} \mathrm{CBS}=\mathrm{CBS}-\mathrm{KNAW}$ Fungal Biodiversity Centre, Utrecht, Netherlands

$-=$ not available 
Fig. 1 One of the equally most parsimonious trees obtained from a heuristic search of the ITS dataset. Bootstrap values obtained from 1,000 replicates along with posterior probabilities are shown at the nodes. The tree was rooted with Neofusicoccum ribis and Phaeobotryosphaeria visci. Isolates identified in this study are indicated in bold . Tree length $=$ 209, $\mathrm{CI}=0.785, \mathrm{RI}=0.944$ and $\mathrm{HI}=0.215$

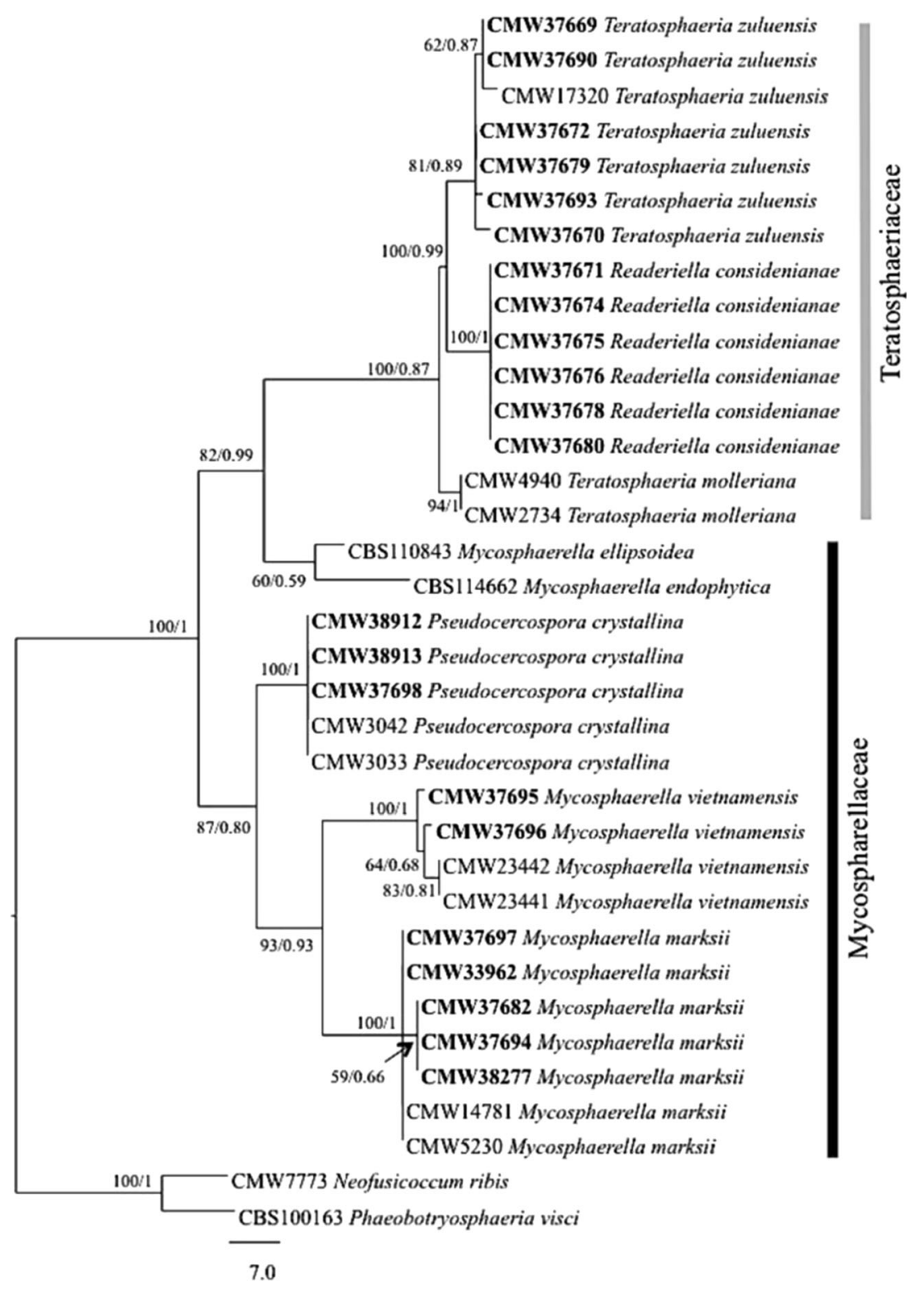

isolated from both trees, whilst M. marksii and M. vietnamensis were isolated solely from $S$. cordatum and $R$. considenianae and $T$. zuluensis were isolated from the $E$. grandis clone. All the identified species were isolated from the leaves of the two trees sampled. No isolates were isolated from the twigs or the trunk increments. The sequence alignments and phylogenetic trees for each gene region as well as the combined analysis were all deposited in TreeBASE (http://purl.org/phylo/treebase/ phylows/study/TB2:S 14876 ? x-access-code= ec92eb8a6492c73537799c2fe03b8a0b\&format=html).

\section{Discussion}

Five species of Mycosphaerellaceae and Teratosphaeriaceae were isolated as endophytes in this study. These fungi were 
Fig. 2 One of the equally most parsimonious trees obtained from a heuristic search of the LSU dataset. Bootstrap values obtained from 1,000 replicates along with posterior probabilities are shown at the nodes. The tree was rooted with Neofusicoccum ribis and Phaeobotryosphaeria visci. Isolates identified in this study are indicated in bold. Tree length $=$ $229, \mathrm{CI}=0.782, \mathrm{RI}=0.947$ and $\mathrm{HI}=0.218$

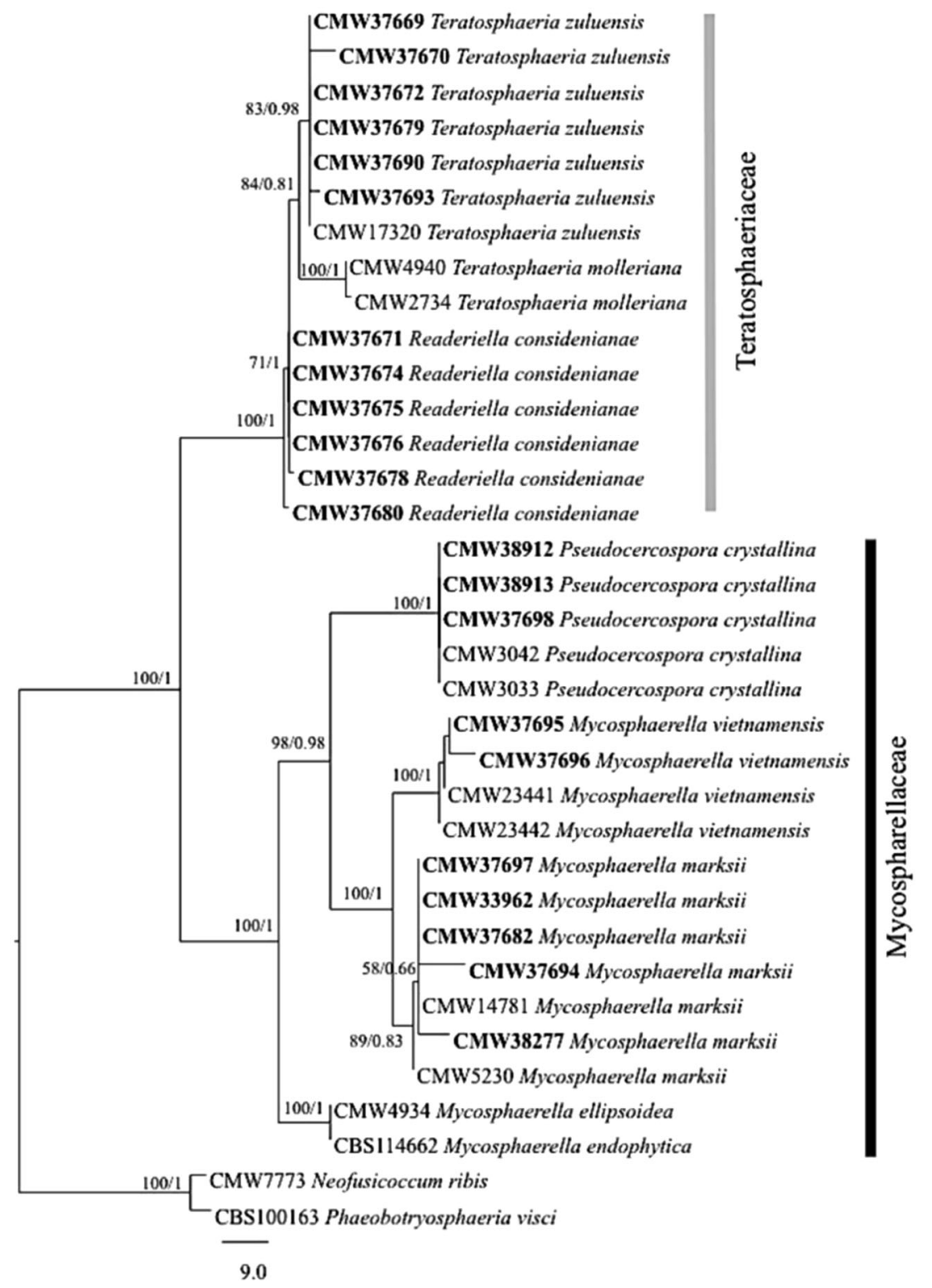

obtained from healthy $S$. cordatum and E. grandis $x E$. camaldulensis trees growing in close proximity to each other, in South Africa. These included a number of pathogens known to occur in South Africa and also fungi that have not previously been recorded in the country.

Even though the sampling in this study was limited, it revealed two new geographical records for the Mycosphaerellaceae. These include $R$. considenianae and $M$. vietnamensis that are recorded from South Africa for the first time. $R$. considenianae has recently been found to occur on E. considenianae in Australia, but is not an important pathogen (Summerell et al. 2006; Taylor et al. 2012). M. vietnamensis is known to occur as a weak pathogen on E. camaldulensis and E. grandis in Vietnam (Burgess et al. 2007). In the present study, it was not only recorded in South Africa for the first time, but it was also found on a non-native Eucalyptus host for the first time.

This study revealed that some fungal species of Mycosphaerellaceae and Teratosphaeriaceae co-occur on S. cordatum and the sampled Eucalyptus clone. Based on their identity in previous publications, other species have the potential to do so. For example, $P$. crystallina was found in the leaves of both $S$. cordatum and the Eucalyptus clone. This fungus is known from leaf spots on E. bicostata as well as on E. grandis $\mathrm{x}$ E. camaldulensis in South Africa (Crous and Wingfield 1996). The fungus was previously known only from South Africa, but has since been found to occur on Eucalyptus in China (Burgess et al. 2007). Its native host is unknown and it could have originated on Eucalyptus and moved to native $S$. cordatum or vice versa. $M$. marksii is not considered an important pathogen. However, it has been 
Fig. 3 One of the equally most parsimonious trees obtained from a heuristic search of the TEF- $1 \alpha$ dataset. Bootstrap values obtained from 1,000 replicates along with posterior probabilities are shown at the nodes. The tree was rooted with Neofusicoccum ribis and Phaeobotryosphaeria visci. Isolates identified in this study are indicated in bold. Tree length $=$ $642, \mathrm{CI}=0.783, \mathrm{RI}=0.945$ and $\mathrm{HI}=0.217$

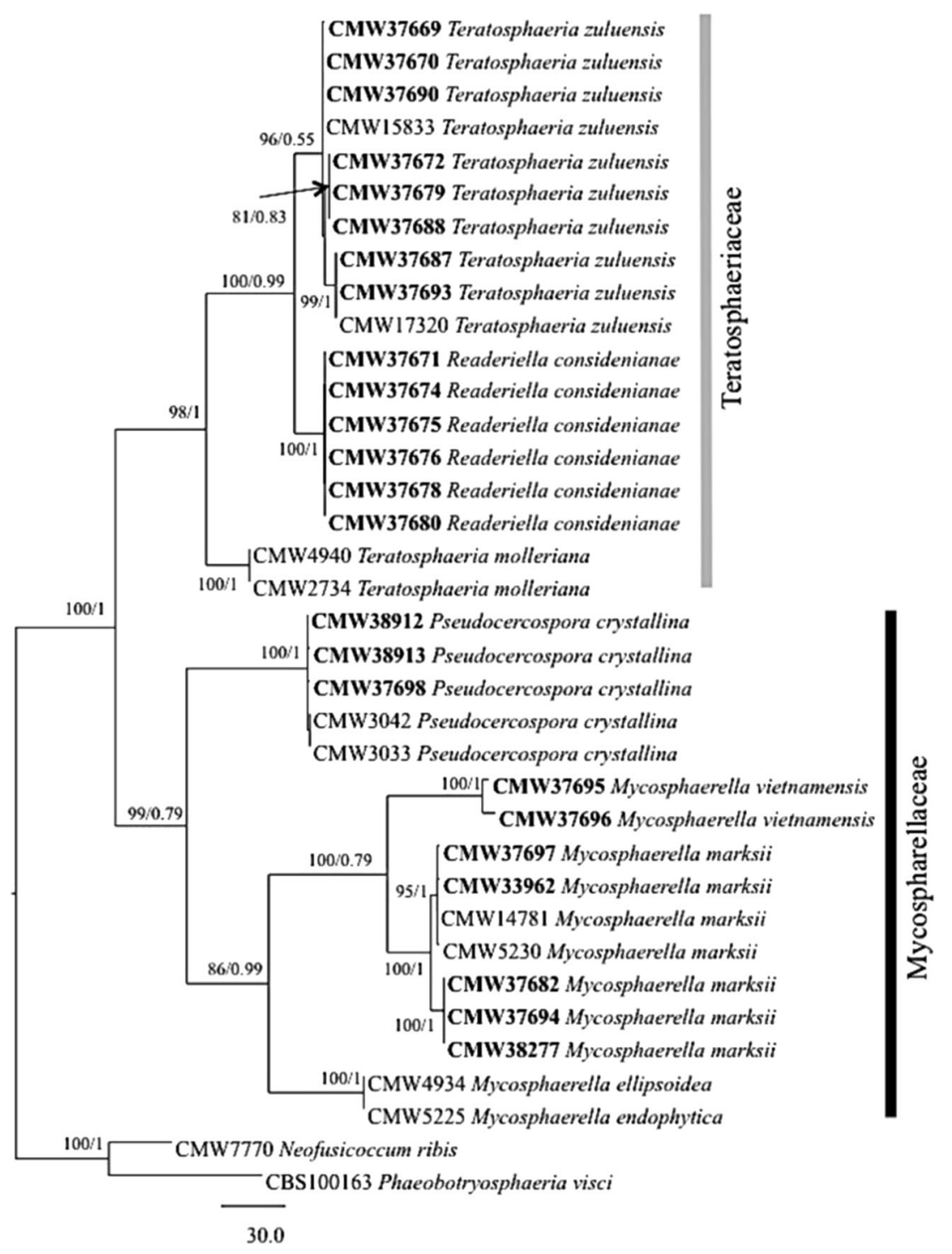

found to constitutively infect the leaves of Eucalyptus in Australia, China, Ethiopia, Indonesia, Madagascar, Portugal, South Africa and Uruguay (Crous and Wingfield 1996; Crous 1998; Hunter et al. 2004; Burgess et al. 2007; Hunter et al. 2011). In this study it was identified from the leaves of S. cordatum, but not from the leaves of the Eucalyptus clone sampled. It seems likely that this fungus has been introduced into South Africa and colonised S. cordatum. M. vietnamensis has been shown to colonise the leaves of $S$. cordatum in this study but is also known to occur in other Eucalyptus spp. as a weak pathogen in South East Vietnam (Burgess et al. 2007).

The ability of species in the Mycosphaerellaceae and Teratosphaeriaceae to co-occur on closely related hosts, such as Eucalyptus and S. cordatum, indicates that they have the capacity to jump to either commercially important trees or, alternatively, they could potentially threaten native trees. As Eucalyptus spp. are not native to South Africa, pathogens may have been introduced that have the potential to colonise native
Myrtaceae spp., such as S. cordatum. However, the opposite may also be true where native trees serve as inoculum sources for fungi that are pathogenic to Eucalyptus (Pavlic et al. 2007; Rodas et al. 2008). This study highlights that the latter may be occurring for leaf infecting fungi but remains largely unrecognised. The results in this study showing evidence of possible cross infections are surprising and the consequence of such cross infections deserves further attention. Crous and Groenewald (2005) suggested that the phenomenon whereby some fungal species move from one host to another in search of their preferred host on which they cause disease, be termed the "pogo-stick hypothesis" (Crous and Groenewald 2005).

Teratosphaeria zuluensis is a well-known and serious pathogen associated with $E$. grandis clones in South Africa, which causes severe cankers on the stems and branches of Eucalyptus trees (Wingfield et al. 1996; Cortinas et al. 2010). In this study, the fungus was isolated from the leaves of the Eucalyptus clone. This was a most unexpected result as 
Fig. 4 One of the equally most parsimonious trees obtained from a heuristic search of the combined ITS, LSU and TEF- $1 \alpha$ datasets. Bootstrap values obtained from 1,000 replicates along with posterior probabilities are shown at the nodes. The tree was rooted with Neofusicoccum ribis and Phaeobotryosphaeria visci. Isolates identified in this study are indicated in bold. Tree length $=$ $1091, \mathrm{CI}=0.775, \mathrm{RI}=0.941$ and $\mathrm{HI}=0.225$

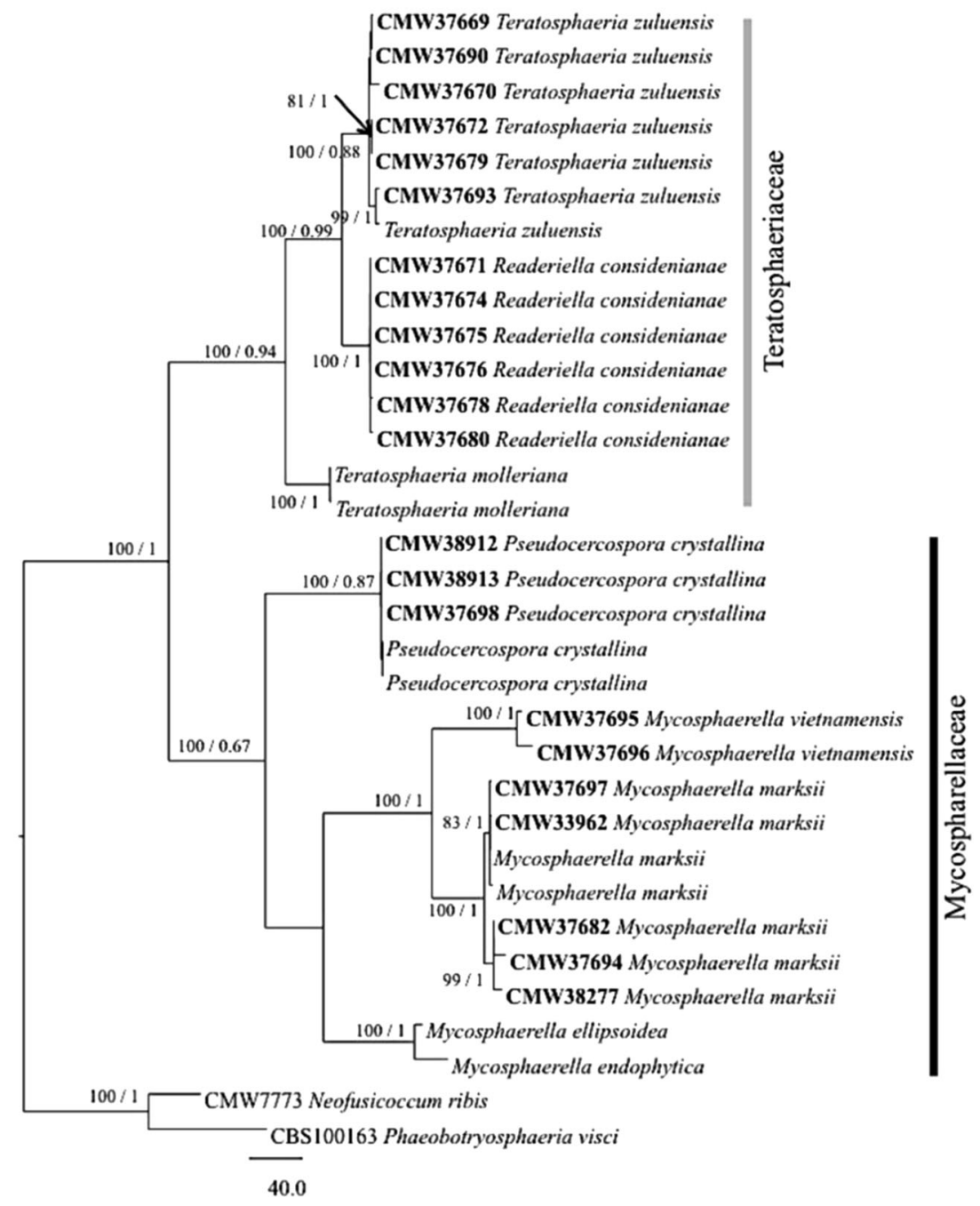

symptoms of infection by the fungus have never been seen on leaves and is found only on green stem and branch tissues. Whether the fungus can act as a pathogen of leaves is unknown and this deserves further study. The presence of this serious pathogen within leaves, however, represents a previously overlooked niche that could represent possible opportunities for it to be moved between areas, countries and continents. This may indeed represent a means by which it was introduced into South Africa, potentially from China where it is thought to be native (Chen et al. 2011).

Table 2 Statistical results for the phylogenetic analysis

\begin{tabular}{|c|c|c|c|c|c|c|c|c|}
\hline \multicolumn{9}{|c|}{ Maximum parsimony } \\
\hline Dataset & Number of taxa & Excluded characters & Included characters & Tree number & Tree length & $\mathrm{CI}$ & RI & $\mathrm{HI}$ \\
\hline ITS & 35 & 400 & 96 & 51 & 196 & 0.760 & 0.944 & 0.240 \\
\hline LSU & 35 & 531 & 136 & 21 & 223 & 0.794 & 0.953 & 0.206 \\
\hline $\mathrm{TEF}-1 \alpha$ & 36 & 40 & 232 & 16 & 642 & 0.783 & 0.945 & 0.217 \\
\hline Combined & 33 & 1023 & 470 & 160 & 1091 & 0.775 & 0.941 & 0.225 \\
\hline \multicolumn{9}{|l|}{ MrBayes } \\
\hline Dataset & Model & Preset state freqpr & & NST & Rates & & Burnin & \\
\hline ITS & $\mathrm{GTR}+\mathrm{G}$ & $(1,1,1,1)$ & & 6 & gamma & & 1,000 & \\
\hline LSU & $\mathrm{GTR}+\mathrm{G}$ & $(1,1,1,1)$ & & 6 & gamma & & 1,000 & \\
\hline TEF-1 $\alpha$ & $\mathrm{GTR}+\mathrm{G}$ & $(1,1,1,1)$ & & 6 & gamma & & 1,000 & \\
\hline Combined & $\mathrm{GTR}+\mathrm{G}$ & $(1,1,1,1)$ & & 6 & gamma & & 1,000 & \\
\hline
\end{tabular}


The isolates characterised in this study were derived from single $S$. cordatum and Eucalyptus trees. This limited sampling in terms of the host, however, revealed three new host and two new geographical reports. It also exposed examples of possible cross infections by potentially pathogenic fungi on these two tree species. This suggests that although Eucalyptus represents a well-studied tree in South Africa, the patterns of occurrence, host preference and ecological role of the Mycosphaereallaceae and the Teratosphaeriaceae remain poorly understood.

Acknowledgments We thank the Thutuka Funding programme of the National Research Foundation (NRF), members of the Tree Protection Co-operative Programme (TPCP) and the Department of Science and Technology (DST)/NRF Centre of Excellence in Tree Health Biotechnology (CTHB), South Africa for financial support. We are also grateful to Dr Ewald Groenewald (CBS-KNAW Fungal Biodiversity Centre; Netherlands), for his valuable assistance with the data analysis and for helpful suggestions regarding the manuscript. We also thank Miss KerryAnne Pillay and Mr Jan Nagel for technical assistance.

\section{References}

Andjic V, Whyte G, Hardy G, Burgess T (2010) New Teratosphaeria species occurring on eucalypts in Australia. Fungal Divers 43:27-38

Bensch K, Groenewald JZ, Dijksterhuis J, Starink-Willemse M, Andersen B, Summerell BA, Shin HD, Dugan FM, Schroers HJ, Braun U (2010) Species and ecological diversity within the Cladosporium cladosporioides complex (Davidiellaceae, Capnodiales). Stud Mycol 67:1-94

Burgess TI, Barber PA, Sufaati S, Xu D, Hardy Gest JDB (2007) Mycosphaerella spp. on Eucalyptus in Asia; new species, new hosts and new records. Fungal Divers 24:135-157

Carbone I, Kohn LM (1990) A method for designing primer sets for speciation studies in filamentous ascomycetes. Mycologia 91:553556

Chen SF, Barnes I, Chungu D, Roux J, Wingfield MJ, Xie YJ, Zhou XD (2011) High population diversity and increasing importance of the Eucalyptus stem canker pathogen, Teratosphaeria zuluensis, in South China. Australas Plant Pathol 40:407-415

Corlett M (1995) An annotated list of the published names in Mycosphaerella and Sphaerella: corrections and additions. Mycotaxon 53:37-56

Cortinas MN, Barnes I, Wingfield MJ, Wingfield BD (2010) Genetic diversity in the Eucalyptus stem pathogen Teratosphaeria zuluensis. Australas Plant Pathol 39:383-393

Crous PW (1998) Mycosphaerella spp. and their anamorphs: associated with leaf spot diseases of Eucalyptus. APS Press, St Paul

Crous PW (1999) Species of Mycosphaerella and related anamorphs occurring on Myrtaceae (excluding Eucalyptus). Mycol Res 103: $607-621$

Crous PW (2009) Taxonomy and phylogeny of the genus Mycosphaerella and its anamorphs. Fungal Divers 38:1-24

Crous PW, Groenewald JZ (2005) Hosts, species and genotypes: opinions versus data. Australas Plant Pathol 34:463-470

Crous PW, Wingfield MJ (1996) Species of Mycosphaerella and their anamorphs associated with leaf blotch disease of Eucalyptus in South Africa. Mycologia 88:441-458

Crous PW, Wingfield MJ, Park RF (1991) Mycosphaerella nubilosa, a synonym of M. molleriana. Mycol Res 95:628-632
Crous PW, Aptroot A, Kang JC, Braun U, Wingfield MJ (2000) The genus Mycosphaerella and its anamorphs. Stud Mycol 45:107-121

Crous PW, Hong L, Wingfield BD, Wingfield MJ (2001a) ITS rDNA phylogeny of selected Mycosphaerella species and their anamorphs occurring on Myrtaceae. Mycol Res 105:425-431

Crous PW, Kang JC, Braun U (2001b) A phylogenetic redefinition of anamorph genera in Mycosphaerella based on ITS rDNA sequence and morphology. Mycologia 93:1081-1101

Crous PW, Groenewald JZ, Mansilla JP, Hunter GC, Wingfield MJ (2004) Phylogenetic reassessment of Mycosphaerella spp. and their anamorphs occurring on Eucalyptus. Stud Mycol 50:195-214

Crous PW, Wingfield MJ, Mansilla JP, Alfenas AC, Groenewald JZ (2006) Phylogenetic reassessment of Mycosphaerella spp. and their anamorphs occurring on Eucalyptus. II. Stud Mycol 55:99-131

Crous PW, Braun U, Groenewald JZ (2007) Mycosphaerella is polyphyletic. Stud Mycol 58:1-32

Crous PW, Groenewald JZ, Summerell BA, Wingfield BD, Wingfield MJ (2009a) Co-occurring species of Teratosphaeria on Eucalyptus. Persoonia 22:38-48

Crous PW, Schoch CL, Hyde KD, Wood AR, Gueidan C, De Hoog GS, Groenewald JZ (2009b) Phylogenetic lineages in the Capnodiales. Stud Mycol 64:17-47

Crous PW, Summerell BA, Carnegie AJ, Wingfield MJ, Hunter GC, Burgess TI, Andjic V, Barber PA, Groenewald JZ (2009c) Unravelling Mycosphaerella: do you believe in genera? Persoonia 23:99-118

Crous PW, Wingfield MJ, Groenewald JZ (2009d) Niche sharing reflects a poorly understood biodiversity phenomenon. Persoonia 22:83-94

de Hoog GS, Gerrits van den Ende AHG (1998) Molecular diagnostics of clinical strains of filamentous Basidiomycetes. Mycoses 41:183-189

Farris JS, Kallersjo M, Kluge AG, Bult C (1994) Testing significance of incongruence. Cladistics 10:315-319

Felsenstein J (1985) Confidence limits on phylogenies: an approach using the bootstrap. Evolution 39:783-791

Hillis DM, Huelsenbeck JP (1992) Signal, noise, and reliability in molecular phylogenetic analyses. J Hered 83:189-195

Hunter GC, Roux J, Wingfield BD, Crous PW, Wingfield MJ (2004) Mycosphaerella species causing leaf disease in South African Eucalyptus plantations. Mycol Res 108:672-681

Hunter GC, Wingfield BD, Crous PW, Wingfield MJ (2006) A multigene phylogeny for species of Mycosphaerella occurring on Eucalyptus leaves. Stud Mycol 55:147-161

Hunter GC, Crous PW, Carnegie AJ, Wingfield MJ (2009) Teratosphaeria nubilosa, a serious leaf disease pathogen of Eucalyptus spp. in native and introduced areas. Mol Plant Pathol 10:1-14

Hunter GC, Crous PW, Carnegie AJ, Burgess TI, Wingfield MJ (2011) Mycosphaerella and Teratosphaeria diseases of Eucalyptus; easily confused and with serious consequences. Fungal Divers 50:145166

Hyde KD, Bussaban B, Paulus B, Crous PW, Lee S, McKenzie EHC, Photita W, Lumyong S (2007) Diversity of saprobic microfungi. Biodivers Conserv 16:7-35

Katoh K, Kuma K, Toh H, Miyata T (2005) MAFFT version 5: improvement in accuracy of multiple sequence alignment; http://mafft.cbrc. jp/alignment/software/. Nucleic Acids Res 33:511-518

Maxwell A, Jackson SL, Dell B, Hardy G (2005) PCR-identification of Mycosphaerella species associated with leaf diseases of Eucalyptus. Mycol Res 109:992-1004

Moller EM, Bahnweg G, Sandermann H, Geiger HH (1992) A simple and efficient protocol for isolation of high molecular weight DNA from filamentous fungi, fruit bodies, and infected plant tissues. Nucleic Acids Res 20:6115-6116

Moncalvo JM, Wang HH, Hseu RS (1995) Phylogenetic relationships in Ganoderma inferred from the internal transcribed spacers and 25S ribosomal DNA sequences. Mycologia 87:223-238 
Nylander JAA (2004) MrModeltest v2. Program distributed by the author. Evolutionary Biology Centre, Uppsala University; https:// github.com/nylander/MrModeltest2

Pavlic D, Slippers B, Coutinho TA, Wingfield MJ (2007) Botryosphaeriaceae occurring on native Syzygium cordatum in South Africa and their potential threat to Eucalyptus. Plant Pathol 56:624-636

Rambaut A, Drummond AJ (2007) Tracer v1. 4;http://tree.bio.ed.ac.uk/ software/tracer/

Rehner SA, Samuels GJ (1995) Moleculoar systematics of Hypocreales: a teleomorph gene phylogeny and the status of their anamorphs. Can J Bot 73:816-823

Rodas CA, Roux RJ, van Wyk M, Wingfield BD, Wingfield MJ (2008) Ceratocystis neglecta sp. nov., infecting Eucalyptus trees in Colombia. Fungal Divers 28:73-84

Ronquist F, Huelsenbeck JP (2003) MrBayes 3: Bayesian phylogenetic inference under mixed models. Bioinformatics 19:1572-1574

Sánchez Márquez S, Bills GF, Zabalgogeazcoa I (2011) Fungal species diversity in juvenile and adult leaves of Eucalyptus globulus from plantations affected by Mycosphaerella leaf disease. Ann Appl Biol 158:177-187

Schubert K, Groenewald JZ, Braun U, Dijksterhuis J, Starink M, Hill CF, Zalar P, De Hoog GS, Crous PW (2007) Biodiversity in the Cladosporium herbarum complex (Davidiellaceae, Capnodiales), with standardisation of methods for Cladosporium taxonomy and diagnostics. Stud Mycol 58:105-156
Summerell BA, Groenewald JZ, Carnegie AJ, Summerbell RC, Crous PW (2006) Eucalyptus microfungi known from culture. 2. Alysidiella, Fusculina and Phlogicylindrium genera nova, with notes on some other poorly known taxa. Fungal Divers 23:323-350

Sutton BC, Crous PW (1997) Lecanostictopsis gen. nov., and related leaf-spotting fungi on Syzygium species. Mycol Res 101:215-225

Swofford DL (2003) \{PAUP*. Phylogenetic analysis using parsimony (* and other methods). Version 4.\}; http://paup.csit.fsu.edu/downl.html

Tamura K, Dudley J, Nei M, Kumar S (2007) MEGA4: molecular evolutionary genetics analysis (MEGA) software version 4.0. Mol Biol Evol 24:1596-1599

Taylor K, Andjic V, Barber PA, Hardy GEJ, Burgess TI (2012) New species of Teratosphaeria associated with leaf diseases on Corymbia calophylla (Marri). Mycol Prog 11:159-169

Vilgalys R, Hester M (1990) Rapid genetic identification and mapping of enzymatically amplified ribosomal DNA from several Cryptococcus species. J Bacteriol 172:4238-4246

White TJ, Bruns T, Lee S and Taylor J (1990) Amplification and direct sequencing of fungal ribosomal RNA genes for phylogenetics. In: PCR protocols a guide to methods and applications, pp. 315-322. Academic Press, New York

Wingfield MJ, Crous PW, Coutinho TA (1996) A serious canker disease of Eucalyptus in South Africa caused by a new species of Coniothyrium. Mycopathologia 136:139-145 